\title{
Recommendations for the treatment of epilepsy in adult patients in general practice in Belgium: an update
}

\author{
Paul Boon · Sebastiaan Engelborghs • Henri Hauman • An Jansen • \\ Lieven Lagae - Benjamin Legros • Michel Ossemann - Bernard Sadzot • \\ Katrien Smets $\cdot$ Etienne Urbain $\cdot$ Kenou van Rijckevorsel
}

Received: 20 March 2012/Accepted: 14 April 2012/Published online: 28 April 2012

(C) The Author(s) 2012. This article is published with open access at Springerlink.com

\begin{abstract}
In 2008, a group of Belgian epilepsy experts published recommendations for antiepileptic drug (AED) treatment of epilepsies in adults and children. Selection of compounds was based on the registration and reimbursement status in Belgium, the level of evidence for efficacy,
\end{abstract}

The authors have been listed alphabetically. P. Boon chaired the epilepsy expert group; furthermore, authors have made equal contributions to this article. This paper has been prepared under the auspices of the Belgian League against Epilepsy.

Translation of these recommendations into clinical practice and the choice of any AED in an individual patient is the sole responsibility of the treating physician. The authors of this article do not assume any responsibility in this respect.

P. Boon $(\square)$

Department of Neurology, Ghent University Hospital,

185 De Pintelaan, 9000 Ghent, Belgium

e-mail: Paul.Boon@Ugent.be

\section{S. Engelborghs}

Department of Neurology and Memory Clinic, Hospital Network Antwerp (ZNA) Middelheim and Hoge Beuken, Institute

Born-Bunge, University of Antwerp, Antwerp, Belgium

H. Hauman

Department of Neurology, Sint-Maarten Hospital,

Duffel, Belgium

\section{A. Jansen}

Department of Paediatric Neurology, University Hospital

Brussels, Free University Brussels, Brussels, Belgium

L. Lagae

Department of Paediatric Neurology, University Hospital,

Leuven, Belgium

B. Legros

Department of Neurology, Hôpital Erasme,

Université Libre de Bruxelles, Brussels, Belgium common daily practice and the personal views and experiences of the authors. In November 2011 the validity of these recommendations was reviewed by the same group of Belgian epilepsy experts who contributed to the preparation of the original paper. The recommendations made in 2008 for initial monotherapy in paediatric patients were still considered to be valid, except for the first choice treatment for childhood absence epilepsy. This update therefore focuses on the treatment recommendations for initial monotherapy and add-on treatment in adult patients. Several other relevant aspects of treatment with AEDs are addressed, including considerations for optimal combination of AEDs (rational polytherapy), pharmacokinetic properties, pharmacodynamic and pharmacokinetic

\section{Ossemann}

Department of Neurology, University Hospital Mont-Godinne,

Université Catholique de Louvain, Yvoir, Belgium

\section{B. Sadzot}

Department of Neurology, University Hospital Centre

Sart-Tilman, Liège, Belgium

K. Smets

Department of Neurology, Antwerp University Hospital,

University of Antwerp, Antwerp, Belgium

E. Urbain

Department of Neurology, Grand Hôpital de Charleroi,

Charleroi, Belgium

K. van Rijckevorsel

Department of Paediatric Neurology, Saint Luc University

Hospital, Université Catholique de Louvain, Brussels, Belgium 
interaction profile, adverse effects, comorbidity, treatment of elderly patients, AED treatment during pregnancy, and generic substitution of AEDs.

Keywords Epilepsy - Antiepileptic drugs - Seizures · Treatment $\cdot$ Recommendations

\section{Introduction}

The number of antiepileptic drugs (AEDs) currently registered in Belgium is considerable and still increasing. In the 1970s only 6 AEDs, benzodiazepines excluded, were available: phenobarbital, phenytoin, ethosuximide, primidone, carbamazepine and valproate. Since the 1990s the number of approved AEDs has increased exponentially, though not all of these compounds are marketed (yet).

Although this large choice of AEDs allows tailoring treatment to the individual patient's needs, it also makes selection of the most suitable compound a complicated task. To provide guidance for the management of epilepsy in general practice in Belgium, a group of experts published recommendations for AED treatment of epilepsies in adults and children in 2008 [1].

The literature and the views of the authors regarding initial monotherapy for seizures in paediatric patients $(<16$ years) have not changed; the recommendations made in 2008 are therefore still considered valid [1]. The present publication focuses on recommendations for AED treatment of epilepsies in adult patients, providing an update on selection of AEDs for initial monotherapy (for focal seizures, primary generalized seizures and type of seizures not yet established) and for add-on treatment of seizures (focal seizures and primary generalized tonic-clonic seizures).

The choice of an AED primarily depends on the efficacy of the compound for controlling the patient's seizure type or in a specific epilepsy syndrome. Other patient-specific factors, such as age, presence of concomitant diseases (including hepatic or renal impairment), use of concomitant medication (including use of other AEDs), sex and childbearing potential should also be taken into consideration. Factors such as pharmacokinetics, tolerability and safety of the AED, pharmacokinetic and pharmacodynamic interaction potential, ease of use and dosing frequency, availability of pharmaceutical formulations, and possibility to rapidly obtain seizure control will also play a role in AED selection.

In addition to providing recommendations for treatment, the present paper will also address some of these patientrelated and AED-related factors relevant for the selection of the optimal compound.

\section{Methodology}

In 2008, recommendations for the AED treatment of epilepsies in general practice in Belgium were published [1]. These recommendations were prepared by a group of Belgian epilepsy experts, based on guidelines for the treatment of epilepsies published by the International League against Epilepsy (ILAE, 2006 [2]), the American Academy of Neurology (AAN, 2004 [3, 4]), the Scottish Intercollegiate Guidelines Network (SIGN, 2003 [5]), and the UK National Institute for Clinical Excellence (NICE, 2004 [6]), and relevant publications of controlled clinical trials with AEDs published after the cut-off dates used in these guidelines. The information from the published guidelines and relevant clinical studies was evaluated and translated into treatment recommendations for the Belgian situation, taking into account the registration status and reimbursement of the compounds and clinical practice in Belgium.

The discussions resulted in recommendations for initial monotherapy and add-on treatment in adults and for initial monotherapy in paediatric patients ( $<16$ years) [1].

In November 2011, the validity of these recommendations was reviewed by the same group of Belgian epilepsy experts that contributed to the preparation of the original paper. Prior to this expert meeting, the scientific literature was searched for international treatment guidelines for epilepsy and relevant controlled clinical trials with AEDs published after preparation of the recommendations in 2008. The criteria used to determine the relevance of the clinical trials were the same as in 2008 [1]. No updates on the ILAE, AAN, SIGN, or NICE guidelines on the treatment of epilepsies have been published since 2008. To the experts' knowledge, no new guidelines for epilepsy treatment have been issued by any other scientific body either.

In a recently published randomized controlled study by Glauser et al. [7], it was shown that ethosuximide and valproic acid are more effective than lamotrigine in the treatment of childhood absence epilepsy, with ethosuximide being associated with fewer adverse attentional effects. Based on this study the authors are of the opinion that both ethosuximide and valproate should be considered first choice in childhood absence epilepsy. This represents the only change in the 2008 treatment recommendations for monotherapy in paediatric patients.

Since the publication of the 2008 recommendations, rufinamide and stiripentol were registered in Belgium; rufinamide for add-on treatment of patients with LennoxGastaut syndrome and stiripentol as adjunctive therapy in patients with Dravet's syndrome. As the 2008 recommendations only covered initial monotherapy in paediatric patients, these registrations do not imply a change of the recommendations for children. 
The present paper focuses on an update of the recommendations for initial monotherapy and for add-on treatment in adult patients.

The following criteria were used to prepare the treatment recommendations in this update:

- The AED is registered and reimbursed in Belgium.

- The AED with the highest level of evidence for efficacy is recommended as first choice. The definitions for the level of evidence were described in detail in the 2008 recommendations [1], and were taken from the ILAE guidelines for monotherapy [2] and the AAN guidelines for add-on treatment [4].

- If the level of evidence for different AEDs is the same or if there is only limited evidence, recommendations are based on personal views and experiences of the authors.

The following definitions are used in the present paper:

First choice First treatment choice

Alternative first choice Compound recommended when certain patient factors (e.g. comorbidity, concomitant medication) or AED-related factors (e.g. pharmacokinetic properties, interaction potential, contraindications, adverse effect profile) preclude the use of the first choice compound.

\section{Recommendations for treatment}

The literature search for papers on monotherapy or add-on treatment with AEDs published since 2008 did not reveal any relevant controlled clinical trials that would lead to a change in the level of evidence for efficacy of the compounds included in Tables 2 and 3.

Initial monotherapy in adults $(\geq 16$ years)

Recommendations for initial monotherapy of seizures in adults are presented in Table 2 .

\section{Focal seizures with/without secondary generalization}

Registered and reimbursed treatment options for monotherapy of focal seizures with or without secondary generalization are carbamazepine, lamotrigine, levetiracetam, pheneturide, phenobarbital, phenytoin, primidone, topiramate, and valproate (Table 1). Since the publication of the recommendations in 2008, no new treatment options have become available for this indication.

Carbamazepine and levetiracetam are recommended as first choice. Both compounds have level A evidence for efficacy [2, 8]. In 2008 levetiracetam was considered alternative first choice (i.e. compound recommended when certain patient factors or compound-related factors precluded use of first choice carbamazepine) because of the limited clinical experience with this compound in monotherapy. Since 2008 clinical experience with levetiracetam has increased considerably. Therefore, both levetiracetam and carbamazepine now are considered first choice for monotherapy of focal seizures with or without secondary generalization.

Lamotrigine, oxcarbazepine, topiramate and valproate are alternative first choices, with level C or B evidence for efficacy in the general adult population. For lamotrigine level A evidence for efficacy was demonstrated in elderly patients [2].

\section{Primary generalized seizures}

The classification "primary generalized seizures" includes tonic-clonic seizures, absences, myoclonic seizures, clonic seizures, tonic seizures and atonic seizures [11]. The registered (and reimbursed) indications of AEDs do not cover all these subtypes of primarily generalized seizures. Registered and reimbursed AEDs for monotherapy of primary generalized tonic-clonic seizures are carbamazepine, lamotrigine, phenobarbital, phenytoin, primidone, topiramate, and valproate. Primidone and valproate are registered and reimbursed for juvenile myoclonic epilepsy (Table 1).

The authors consider valproate to be first choice for the treatment of primary generalized seizures, except in women of childbearing age. Lamotrigine, levetiracetam and topiramate are alternative first choices (Table 2). The level of evidence for efficacy of the AEDs in the treatment of primary generalized seizures is not known. Clinical studies have focused on particular subtypes, such as primary generalized tonic-clonic seizures or JME. The efficacy of lamotrigine is best documented against primarily generalized tonic-clonic seizures, absence seizures, and drop attacks associated with Lennox-Gastaut syndrome [15]. It is less effective than valproate in syndromes associated with myoclonic manifestations or absences [15], and may induce or aggravate myoclonic seizures. The efficacy of levetiracetam is best documented against primarily generalized tonic-clonic seizures, and myoclonic seizures [15]; information on its efficacy against tonic and atonic seizures is lacking. The efficacy of topiramate is best documented against primarily generalized tonic-clonic seizures and drop attacks associated with Lennox-Gastaut syndrome. There is no information available on the efficacy of topiramate against absence seizures.

Carbamazepine may be a valuable alternative first choice for the treatment of primary generalized tonicclonic seizures, but is not effective for other types of 
Table 1 Reimbursed and not reimbursed indications of AEDs (ATC code N03) registered in Belgium

\begin{tabular}{|c|c|c|c|c|c|c|}
\hline \multirow[t]{2}{*}{ AED } & \multirow{2}{*}{$\begin{array}{l}\text { Focal seizures with/ } \\
\text { without secondary } \\
\text { generalization }\end{array}$} & \multicolumn{3}{|c|}{ Primary generalized seizures } & \multirow{2}{*}{$\begin{array}{l}\text { Other reimbursed } \\
\text { indications }\end{array}$} & \multirow{2}{*}{$\begin{array}{l}\text { Approved but not } \\
\text { reimbursed } \\
\text { indications }^{\mathrm{a}}\end{array}$} \\
\hline & & $\begin{array}{l}\text { Primary generalized } \\
\text { tonic-clonic } \\
\text { seizures }\end{array}$ & $\begin{array}{l}\text { Juvenile myoclonic } \\
\text { epilepsy }\end{array}$ & Other & & \\
\hline Carbamazepine & $\begin{array}{l}\text { Mono- and add-on } \\
\text { therapy: } \\
\text { adults }+ \text { children }\end{array}$ & $\begin{array}{l}\text { Mono- and add-on } \\
\text { therapy: } \\
\text { adults }+ \text { children }\end{array}$ & & & & \\
\hline Eslicarbazepine $^{\mathrm{b}}$ & & & & & & $\begin{array}{l}\text { Eslicarbazepine is } \\
\text { indicated as } \\
\text { adjunctive therapy in } \\
\text { adults with focal } \\
\text { seizures with or } \\
\text { without secondary } \\
\text { generalisation }\end{array}$ \\
\hline Ethosuximide & & & & $\begin{array}{l}\text { Absence } \\
\text { epilepsy; } \\
\text { atonic } \\
\text { seizures, } \\
\text { myoclonia }\end{array}$ & & \\
\hline Felbamate & & & & & $\begin{array}{l}\text { Add-on treatment in } \\
\text { patients with Lennox- } \\
\text { Gastaut syndrome in } \\
\text { adults and children } \\
\geq 4 \text { years (when not } \\
\text { responding to any } \\
\text { other relevant AED) }\end{array}$ & \\
\hline Gabapentin & $\begin{array}{l}\text { Add-on treatment: } \\
\text { adults }+ \text { children }^{\mathrm{c}}\end{array}$ & & & & & $\begin{array}{l}\text { Monotherapy of } \\
\text { partial-onset epilepsy } \\
\text { with/without } \\
\text { secondary } \\
\text { generalization in } \\
\text { adults and children } \\
>12 \text { years }\end{array}$ \\
\hline Lacosamide & $\begin{array}{l}\text { Add-on treatment: } \\
\text { adults + children } \\
\geq 16 \text { years after } \\
\text { failure of therapy } \\
\text { with at least } 3 \\
\text { AEDs }\end{array}$ & & & & & \\
\hline \multirow[t]{2}{*}{ Lamotrigine } & $\begin{array}{l}\text { Monotherapy: } \\
\text { adults + children } \\
\geq 12 \text { years }\end{array}$ & $\begin{array}{l}\text { Monotherapy: } \\
\text { adults + children } \\
\geq 12 \text { years }\end{array}$ & & & & \multirow{2}{*}{$\begin{array}{l}\text { Add-on treatment of } \\
\text { Lennox-Gastaut } \\
\text { syndrome in adults } \\
\text { and children }\end{array}$} \\
\hline & $\begin{array}{l}\text { Add-on treatment: } \\
\text { adults }+ \text { children }^{\mathrm{d}}\end{array}$ & $\begin{array}{l}\text { Add-on treatment: } \\
\text { adults }+ \text { children }^{\text {a }}\end{array}$ & & & & \\
\hline \multirow[t]{2}{*}{ Levetiracetam } & $\begin{array}{l}\text { Monotherapy: } \\
\text { adults }+ \text { children } \\
\geq 16 \text { years }\end{array}$ & & $\begin{array}{l}\text { Add-on treatment: } \\
\text { adults and } \\
\text { children }\end{array}$ & & & \multirow{2}{*}{$\begin{array}{l}\text { Add-on treatment of } \\
\text { primary generalized } \\
\text { tonic-clonic seizures } \\
\text { in adults and children } \\
>12 \text { years }\end{array}$} \\
\hline & $\begin{array}{l}\text { Add-on treatment: } \\
\text { adults }+ \text { children } \\
\geq 1 \text { month }\end{array}$ & & $\geq 12$ years & & & \\
\hline Oxcarbazepine & $\begin{array}{l}\text { Add-on therapy: } \\
\text { adults }+ \text { children } \\
\geq 6 \text { years }\end{array}$ & & & & & $\begin{array}{l}\text { Monotherapy of } \\
\text { partial-onset epilepsy } \\
\text { with/without } \\
\text { secondary } \\
\text { generalization in } \\
\text { adults and children } \\
>6 \text { years }\end{array}$ \\
\hline Pheneturide & $\begin{array}{l}\text { Mono- and add-on } \\
\text { therapy: } \\
\text { adults }+ \text { children } \\
\geq 2 \text { years }\end{array}$ & & & & & \\
\hline
\end{tabular}


Table 1 continued

\begin{tabular}{|c|c|c|c|c|c|c|}
\hline \multirow[t]{2}{*}{ AED } & \multirow{2}{*}{$\begin{array}{l}\text { Focal seizures with/ } \\
\text { without secondary } \\
\text { generalization }\end{array}$} & \multicolumn{3}{|c|}{ Primary generalized seizures } & \multirow{2}{*}{$\begin{array}{l}\text { Other reimbursed } \\
\text { indications }\end{array}$} & \multirow{2}{*}{$\begin{array}{l}\text { Approved but not } \\
\text { reimbursed } \\
\text { indications }^{\text {a }}\end{array}$} \\
\hline & & $\begin{array}{l}\text { Primary generalized } \\
\text { tonic-clonic } \\
\text { seizures }\end{array}$ & $\begin{array}{l}\text { Juvenile myoclonic } \\
\text { epilepsy }\end{array}$ & Other & & \\
\hline Phenobarbital $^{\mathrm{f}}$ & $\begin{array}{l}\text { Mono- and add-on } \\
\text { therapy: } \\
\text { adults + children }\end{array}$ & $\begin{array}{l}\text { Mono- and add-on } \\
\text { therapy: adults } \\
\text { and children }\end{array}$ & & & & \\
\hline Phenytoin & $\begin{array}{l}\text { Mono- and add-on } \\
\text { therapy: } \\
\text { adults + children }\end{array}$ & $\begin{array}{l}\text { Mono- and add-on } \\
\text { therapy: } \\
\text { adults + children }\end{array}$ & & & & \\
\hline Pregabalin & $\begin{array}{l}\text { Add-on treatment: } \\
\text { adults }\end{array}$ & & & & & \\
\hline Primidone & $\begin{array}{l}\text { Mono- and add-on } \\
\text { therapy: } \\
\text { adults + children }\end{array}$ & $\begin{array}{l}\text { Mono- and add-on } \\
\text { therapy: } \\
\text { adults + children }\end{array}$ & $\begin{array}{l}\text { Mono- and add-on } \\
\text { therapy: adults } \\
\text { and children }\end{array}$ & & & \\
\hline Retigabine & $\begin{array}{l}\text { Add-on treatment: } \\
\text { adults }+ \text { children } \\
\geq 18 \text { years after } \\
\text { failure of therapy } \\
\text { with at least } 3 \\
\text { AEDs }\end{array}$ & & & & & \\
\hline Rufinamide $^{\mathrm{g}}$ & & & & & $\begin{array}{l}\text { Add-on treatment in } \\
\text { patients with Lennox- } \\
\text { Gastaut syndrome in } \\
\text { adults and children } \\
\geq 4 \text { years (after failure } \\
\text { of at least } 2 \text { treatments } \\
\text { with monotherapy or } \\
\text { combinations } \\
\text { including valproate or } \\
\text { topiramate and/or } \\
\text { lamotrigine) }\end{array}$ & \\
\hline Stiripentol & & & & & $\begin{array}{l}\text { Combination treatment } \\
\text { with valproate and } \\
\text { clobazam of patients } \\
\text { with Dravet's } \\
\text { syndrome (severe } \\
\text { myoclonic epilepsy of } \\
\text { infancy) when seizures } \\
\text { are insufficiently } \\
\text { controlled by } \\
\text { valproate/clobazam }\end{array}$ & \\
\hline Tiagabine & $\begin{array}{l}\text { Add-on treatment: } \\
\text { adults }+ \text { children } \\
\geq 12 \text { years }\end{array}$ & & & & & \\
\hline Topiramate & $\begin{array}{l}\text { Monotherapy: } \\
\text { adults }+ \text { children } \\
\geq 6 \text { years } \\
\text { Add-on treatment: } \\
\text { adults }+ \text { children } \\
\geq 2 \text { years }\end{array}$ & $\begin{array}{l}\text { Monotherapy: } \\
\text { adults }+ \text { children } \\
\geq 6 \text { years } \\
\text { Add-on treatment: } \\
\text { adults }+ \text { children } \\
\geq 2 \text { years }\end{array}$ & & & $\begin{array}{l}\text { Add-on treatment in } \\
\text { patients with Lennox- } \\
\text { Gastaut syndrome in } \\
\text { adults and children } \\
\geq 2 \text { years }\end{array}$ & \\
\hline Valproate & $\begin{array}{l}\text { Mono- and add-on } \\
\text { therapy: } \\
\text { adults + children }\end{array}$ & $\begin{array}{l}\text { Mono- and add-on } \\
\text { therapy: } \\
\text { adults + children }\end{array}$ & $\begin{array}{l}\text { Mono- and add-on } \\
\text { therapy: } \\
\text { adults }+ \text { children }\end{array}$ & $\begin{array}{l}\text { Mono- and } \\
\text { add-on } \\
\text { therapy } \\
\text { for } \\
\text { absence } \\
\text { epilepsy } \\
\text { in adults } \\
\text { and } \\
\text { children }\end{array}$ & $\begin{array}{l}\text { Mono- and add-on } \\
\text { therapy in patients } \\
\text { with Lennox-Gastaut } \\
\text { syndrome, West } \\
\text { syndrome }\end{array}$ & \\
\hline
\end{tabular}


Table 1 continued

\begin{tabular}{|c|c|c|c|c|c|c|}
\hline \multirow[t]{2}{*}{ AED } & \multirow{2}{*}{$\begin{array}{l}\text { Focal seizures with/ } \\
\text { without secondary } \\
\text { generalization }\end{array}$} & \multicolumn{3}{|c|}{ Primary generalized seizures } & \multirow{2}{*}{$\begin{array}{l}\text { Other reimbursed } \\
\text { indications }\end{array}$} & \multirow{2}{*}{$\begin{array}{l}\text { Approved but not } \\
\text { reimbursed } \\
\text { indications }^{\mathrm{a}}\end{array}$} \\
\hline & & $\begin{array}{l}\text { Primary generalized } \\
\text { tonic-clonic } \\
\text { seizures }\end{array}$ & $\begin{array}{l}\text { Juvenile myoclonic } \\
\text { epilepsy }\end{array}$ & Other & & \\
\hline Vigabatrin & $\begin{array}{l}\text { Add-on treatment } \\
\text { (last choice): } \\
\text { adults }+ \text { children }\end{array}$ & & & & $\begin{array}{l}\text { Monotherapy of } \\
\text { infantile spasms (West } \\
\text { syndrome) }\end{array}$ & \\
\hline Zonisamide $^{\mathrm{h}}$ & & & & & & $\begin{array}{l}\text { Zonisamide is } \\
\text { indicated as } \\
\text { adjunctive therapy in } \\
\text { the treatment of adult } \\
\text { patients with partial } \\
\text { seizures, with or } \\
\text { without secondary } \\
\text { generalization }\end{array}$ \\
\hline
\end{tabular}

Source: FAGG/AFMPS 14-12-2011[Federaal Agentschap voor Geneesmiddelen en Gezondheidsproducten/Agence Fédérale des Médicaments et des Produits de Santé (http://www.fagg-afmps.be)]/RIZIV/INAMI 01-01-2012 [Rijksinstituut voor ziekte- en invaliditeitsverzekering (RIZIV); Institut national d'assurance maladie-invalidité (INAMI); (http://www.inami.fgov.be; http://www.riziv.fgov.be)]

${ }^{\text {a }}$ The mentioned indications are not always registered for all brands/products

${ }^{\mathrm{b}}$ Eslicarbazepine (Exalief; Zebinix) is not (yet) marketed in Belgium

${ }^{c}$ Some brands specify an age limit of $\geq 6$ years. Reimbursement criteria do not specify an age limit

${ }^{\mathrm{d}}$ Age limit varies among brands

${ }^{\text {e }}$ For some brands limited to children $>2$ years

${ }^{\mathrm{f}}$ Magisterial preparation for paediatric use, fully reimbursed

g Rufinamide (Inovelon) is not (yet) marketed in Belgium

${ }^{\mathrm{h}}$ Zonisamide (Zonegran) is not (yet) marketed in Belgium

Table 2 Initial monotherapy of seizures in adults ( $\geq 16$ years)

\begin{tabular}{|c|c|c|c|c|c|}
\hline & First choice & $\begin{array}{l}\text { Level of } \\
\text { evidence } \\
\text { for efficacy }\end{array}$ & $\begin{array}{l}\text { Alternative first } \\
\text { choice }\end{array}$ & $\begin{array}{l}\text { Level of } \\
\text { evidence } \\
\text { for efficacy }\end{array}$ & Remarks \\
\hline $\begin{array}{l}\text { Focal seizures with/ } \\
\text { without secondary } \\
\text { generalization }\end{array}$ & $\begin{array}{l}\text { Carbamazepine } \\
\text { Levetiracetam }\end{array}$ & A & $\begin{array}{l}\text { Valproate } \\
\text { Lamotrigine } \\
\text { Oxcarbazepine } \\
\text { Topiramate }\end{array}$ & $\begin{array}{l}\mathrm{B} \\
\mathrm{C}\end{array}$ & $\begin{array}{l}\text { Levetiracetam has a better pharmacokinetic and safety } \\
\text { profile than carbamazepine, with no potential for drug } \\
\text { interactions } \\
\text { For lamotrigine the overall level of evidence for } \\
\text { efficacy is C. Level A evidence for efficacy was } \\
\text { obtained in elderly patients }\end{array}$ \\
\hline $\begin{array}{l}\text { Primary generalized } \\
\text { seizures }\end{array}$ & Valproate & - & $\begin{array}{l}\text { Lamotrigine } \\
\text { Levetiracetam } \\
\text { Topiramate }\end{array}$ & - & $\begin{array}{l}\text { The efficacy of lamotrigine is best documented against } \\
\text { primarily generalized tonic-clonic seizures, absence } \\
\text { seizures, and drop attacks associated with Lennox- } \\
\text { Gastaut syndrome [15] Lamotrigine may induce or } \\
\text { aggravate myoclonic seizures } \\
\text { The efficacy of levetiracetam is best documented } \\
\text { against primarily generalized tonic-clonic seizures, } \\
\text { and myoclonic seizures. Efficacy against tonic and } \\
\text { atonic seizures has not been documented [15] } \\
\text { The efficacy of topiramate is best documented against } \\
\text { primarily generalized tonic-clonic seizures and drop } \\
\text { attacks associated with Lennox-Gastaut syndrome. } \\
\text { Efficacy against absence seizures has not been } \\
\text { documented [15] }\end{array}$ \\
\hline
\end{tabular}

First choice first treatment choice, Alternative first choice compound recommended when certain patient factors (e.g. comorbidity, concomitant medication) or compound-related factors (e.g. pharmacokinetic properties, interaction potential, adverse effect profile) preclude the use of the first choice compound, Level of evidence for efficacy the criteria used to establish the level of evidence for efficacy are taken from Glauser et al. [7] 
Table 3 Add-on treatment of seizures in adults ( $\geq 16$ years)

\begin{tabular}{|c|c|c|}
\hline & $\begin{array}{l}\text { Recommended } \\
\text { AEDs }\end{array}$ & Remarks \\
\hline $\begin{array}{l}\text { Focal seizures with/without } \\
\text { secondary generalization }\end{array}$ & $\begin{array}{l}\text { Carbamazepine } \\
\text { Gabapentin } \\
\text { Lacosamide } \\
\text { Lamotrigine } \\
\text { Levetiracetam } \\
\text { Oxcarbazepine } \\
\text { Pregabalin } \\
\text { Retigabine } \\
\text { Tiagabine } \\
\text { Topiramate } \\
\text { Valproate }\end{array}$ & $\begin{array}{l}\text { All AEDs are efficacious as add-on treatment of epilepsy in adults }{ }^{\mathrm{a}} \text {, and are considered } \\
\text { first choice. The AEDs are listed in alphabetical order } \\
\text { Carbamazepine has been used in clinical practice for over } 30 \text { years, but has a high } \\
\text { potential for pharmacokinetic interactions } \\
\text { Gabapentin, levetiracetam and pregabalin have the most favourable pharmacokinetic and } \\
\text { safety profile, and no potential for drug interactions } \\
\text { Vigabatrin is also registered and reimbursed for add-on treatment of partial-onset epilepsy, } \\
\text { but should only be used when all other compounds are ineffective, because it has a very } \\
\text { unfavourable safety profile (concentric visual field defects) } \\
\text { Lacosamide and retigabine are reimbursed for patients in whom treatment with at least } 3 \\
\text { other AEDs has failed }\end{array}$ \\
\hline $\begin{array}{l}\text { Primary generalized } \\
\text { tonic-clonic seizures }\end{array}$ & $\begin{array}{l}\text { Carbamazepine } \\
\text { Lamotrigine } \\
\text { Levetiracetam } \\
\text { Topiramate } \\
\text { Valproate }\end{array}$ & $\begin{array}{l}\text { All AEDs are efficacious as add-on treatment of primary generalized tonic-clonic seizures } \\
\text { in adults }{ }^{\mathrm{a}} \text {, and are considered first choice. The AEDs are listed in alphabetical order }\end{array}$ \\
\hline
\end{tabular}

${ }^{\text {a }}$ For all newer AEDs the level of evidence for efficacy is A (the criteria used to establish the level of evidence for efficacy are taken from French et al. [3, 4]. No add-on studies have been performed with the older AEDs; efficacy of these compounds is considered to be established during long-term clinical experience

primary generalized seizures, and may induce or aggravate myoclonic seizures and absences.

\section{Type of seizures not (yet) established}

If starting the AED treatment is required prior to establishing seizure type, a broad spectrum AED should be used, such as valproate, lamotrigine, levetiracetam and topiramate, taking into account the relative benefits and risks of each of these compounds.

Add-on treatment of seizures in adult patients ( $\geq 16$ years)

In the consensus proposal of the ILAE Commission on Therapeutic Strategies, published in 2010, drug-resistant epilepsy is defined as "failure of adequate trials of two tolerated and appropriately chosen and used AED schedules (whether as monotherapies or in combination) to achieve sustained seizure freedom" [9].

Combination/add-on therapy can be beneficial in patients who did not respond to monotherapy. Compounds recommended for add-on treatment are presented in Table 3. Carbamazepine, gabapentin, lacosamide, lamotrigine, levetiracetam, oxcarbazepine, pregabalin, retigabine, tiagabine, topiramate, and valproate are all considered first choice for add-on treatment of focal seizures with or without secondary generalization. For all newer AEDs the level of evidence for efficacy is A. No add-on studies have been performed with the older AEDs, but the efficacy of these compounds is considered to be established during long-term clinical experience. Lacosamide and retigabine are reimbursed for patients in whom treatment with at least 3 other AEDs has failed. The other registered and reimbursed AEDs (pheneturide, phenytoin, phenobarbital, primidone, and vigabatrin) are not recommended, because of their unfavourable pharmacokinetic and/or safety profile. Eslicarbazepine ${ }^{1}$ and zonisamide ${ }^{2}$ are registered for add-on treatment of focal seizures, but are not yet marketed/reimbursed in Belgium.

Carbamazepine, lamotrigine, levetiracetam, topiramate and valproate are recommended as first choice for add-on treatment of primary generalized tonic-clonic seizures. For lamotrigine, levetiracetam and topiramate the level of evidence for efficacy is A. Efficacy of carbamazepine and valproate is considered to be established during long-term clinical experience. Phenytoin and primidone are not recommended as first choice for this indication, because of their unfavourable pharmacokinetic and/or safety profile.

The large number of possible combinations of two or more AEDs has led to an increased interest in combination strategies. The goals of "rational polytherapy" are to maximize seizure control and minimize adverse effects. Ideal combinations are those which display pharmacodynamic

\footnotetext{
${ }^{1}$ Exalief; Zebinix

2 Zonegran.
} 
synergism, which ideally may lead to improved efficacy without a proportional increase in toxicity $[12,13]$.

Theoretically it may be assumed that combining AEDs with different mechanisms of action will provide a better potential for additive or even synergistic efficacy and/or a more favourable tolerability profile, and may also be more likely to be effective against a broad range of seizure types in patients with refractory epilepsy compared to combining AEDs with the same mechanism of action [12-14]. There are some indications from the literature on animal models of seizures and epilepsy to confirm this view [12-14], but convincing evidence from non-clinical or clinical studies is lacking.

It should be noted that the mechanism-of-action-based "rational polytherapy" approach is seriously hampered by the lack of knowledge on the processes underlying seizure generation and propagation, and the lack of knowledge on the exact mechanism(s) of action of most AEDs, with many AEDs having multiple pharmacodynamic effects [13].

Table 4 Pharmacokinetic profile rating and pharmaceutical formulations of the AEDs recommended in Tables 2 and 3

\begin{tabular}{|c|c|c|}
\hline AED & $\begin{array}{l}\text { Pharmacokinetic } \\
\text { profile rating } \\
\text { of } \mathrm{AEDs}^{\mathrm{a}}\end{array}$ & $\begin{array}{l}\text { Pharmaceutical } \\
\text { formulations }\end{array}$ \\
\hline Carbamazepine & 50 & $\begin{array}{l}\text { Tablets } \\
\text { Oral solution/syrup }\end{array}$ \\
\hline Gabapentin & 89 & $\begin{array}{l}\text { Tablets } \\
\text { Capsules }\end{array}$ \\
\hline Lacosamide & 96 & $\begin{array}{l}\text { Tablets } \\
\text { I.V. formulation }\end{array}$ \\
\hline Lamotrigine & 73 & Orodispersible tablet \\
\hline Levetiracetam & 96 & $\begin{array}{l}\text { Tablet } \\
\text { Oral solution } \\
\text { I.V. formulation }\end{array}$ \\
\hline Oxcarbazepine & 77 & Tablets \\
\hline Pregabalin & 89 & Capsules \\
\hline Retigabine & NA & Tablets \\
\hline Tiagabine & 67 & Tablets \\
\hline Topiramate & 79 & $\begin{array}{l}\text { Tablets } \\
\text { Capsules }\end{array}$ \\
\hline Valproate & 52 & $\begin{array}{l}\text { Capsules } \\
\text { Controlled-release capsules } \\
\text { Controlled-release tablets } \\
\text { Enteric-coated capsules } \\
\text { Oral solution/syrup } \\
\text { I.V. formulation }\end{array}$ \\
\hline
\end{tabular}

NA no information available

${ }^{a}$ Data taken from Panayiotopoulos [16]; 3-point rating system based on the following parameters: oral absorption, kinetics, plasma protein binding, elimination metabolism, drug interactions and dosing frequency (see Patsalos [17])

${ }^{b}$ Not reimbursed
There is more scientific evidence in favour of pharmacodynamic interaction with respect to adverse effects. When adverse effects of co-administered drugs are similar, combining these drugs may lead to a "threshold" of tolerability being exceeded for that particular side effect. Use of combinations of drugs that block voltage-dependent sodium channels (carbamazepine, lacosamide, lamotrigine, oxcarbazepine) is more likely to produce neurotoxic side effects, such as dizziness, diplopia and ataxia [12, 14]. Since robust evidence to support rational polytherapy is still very limited, the choice of drug combinations in clinical practice will have to be tailored on a case-by-case basis [13].

\section{Specific considerations}

Pharmacokinetic properties and pharmacokinetic interaction profile

Most patients with epilepsy are treated for several years and many need life-long treatment with AEDs. Several patients may be treated with more than one AED, and the likelihood of concomitant treatment with drugs for other diseases (both related and not related to epilepsy) at any point in their lives is high. The absence of a potential for drug interactions is therefore an important positive feature of any AED, which will highly increase its ease of use.

Information on the pharmacokinetic profile of all AEDs included in Tables 2 and 3 is presented in Table 4. The pharmacokinetic profile ratings are taken from the handbook on epilepsy and epilepsy treatment by Panayiotopoulos [16]. The pharmacokinetic profile rating is based on the rating system described by Patsalos [17]. The pharmacokinetic characteristics included in this rating system are: oral absorption (speed of absorption, bioavailability, affected or not by food), kinetics (linearity, saturability), extent of plasma protein binding, extent of renal elimination, metabolism (hepatic, inducible, autoinducible, active metabolites), pharmacokinetic drug interactions (affected by other AEDs, affects other AEDs, affected by other drugs, affects other drugs), and dosing frequency. All parameters are scored on a 3-point rating scale, with 3 being the most favourable score. The score presented in Table 4 is expressed as a percentage of the maximum possible score. Lacosamide and levetiracetam have the highest score $(96 \%)$, followed by gabapentin and pregabalin (both $89 \%$ ). Carbamazepine and valproate have the lowest scores (50 and $52 \%$, respectively).

The use of an AED with a high potential for pharmacokinetic interactions may alter the plasma concentrations of the other AEDs in the combination, thereby affecting their efficacy or increasing the risk of side effects. 
Table 5 Most important adverse effects of the AEDs recommended in Tables 2 and 3

\begin{tabular}{|c|c|c|}
\hline AED & Most common adverse effects (occurring in $>10 \%$ of the patients) ${ }^{a}$ & Other important adverse events ${ }^{\mathrm{b}}$ \\
\hline Carbamazepine & $\begin{array}{l}\text { Central nervous system: dizziness, ataxia, sleepiness } \\
\text { Gastrointestinal: nausea, vomiting } \\
\text { Skin: allergic dermatitis, urticaria (may become serious) } \\
\text { Other: leukopenia, tiredness, increased gamma-GT levels (usually not clinically } \\
\text { relevant) }\end{array}$ & $\begin{array}{l}\text { Diplopia } \\
\text { Weight gain } \\
\text { Hyponatraemia } \\
\text { (aplastic) anaemia } \\
\text { Serious dermatologic reactions } \\
\text { (Stevens-Johnson syndrome) }\end{array}$ \\
\hline Gabapentin & $\begin{array}{l}\text { Central nervous system: dizziness, ataxia, sleepiness } \\
\text { Other: viral infection, tiredness, fever }\end{array}$ & Weight gain \\
\hline Lacosamide & $\begin{array}{l}\text { Central nervous system: dizziness } \\
\text { Gastrointestinal: nausea } \\
\text { Other: headache, diplopia }\end{array}$ & $\begin{array}{l}\text { Dose-related increase in PR-interval } \\
\text { (atrioventricular block) }\end{array}$ \\
\hline Lamotrigine & $\begin{array}{l}\text { Central nervous system: dizziness, ataxia, somnolence } \\
\text { Gastrointestinal: nausea, vomiting } \\
\text { Skin: rash } \\
\text { Other: headache, diplopia, blurred vision }\end{array}$ & $\begin{array}{l}\text { Insomnia } \\
\text { Serious dermatologic reactions } \\
\text { (Stevens-Johnson syndrome) } \\
\text { Hypersensitivity syndrome }\end{array}$ \\
\hline Levetiracetam & $\begin{array}{l}\text { Central nervous system: somnolence } \\
\text { Other: asthenia (tiredness) }\end{array}$ & $\begin{array}{l}\text { Dizziness } \\
\text { Aggressive behaviour (irritability, } \\
\text { hostility) }\end{array}$ \\
\hline Oxcarbazepine & $\begin{array}{l}\text { Central nervous system: dizziness, sleepiness } \\
\text { Gastrointestinal: nausea, vomiting } \\
\text { Other: headache, tiredness, diplopia }\end{array}$ & $\begin{array}{l}\text { Ataxia } \\
\text { Rash } \\
\text { Serious dermatologic reactions } \\
\quad \text { (Stevens-Johnson syndrome) } \\
\text { Hyponatraemia }\end{array}$ \\
\hline Pregabalin & Central nervous system: dizziness, sleepiness & Weight gain \\
\hline Retigabine & $\begin{array}{l}\text { Central nervous system: dizziness, somnolence } \\
\text { Other: fatigue }\end{array}$ & $\begin{array}{l}\text { Urinary retention } \\
\text { QT interval prolongation } \\
\text { Confusional state, psychotic symptoms } \\
\text { and hallucinations }\end{array}$ \\
\hline Tiagabine & $\begin{array}{l}\text { Central nervous system: dizziness, somnolence, depressed mood, nervousness, } \\
\text { concentration disturbances, tremor } \\
\text { Other: tiredness }\end{array}$ & - \\
\hline Topiramate & $\begin{array}{l}\text { Central nervous system: dizziness, sleepiness, depression, paraesthesia } \\
\text { Gastrointestinal: diarrhoea, nausea } \\
\text { Other: tiredness, weight loss, nasopharyngitis }\end{array}$ & $\begin{array}{l}\text { Speech disorders } \\
\text { Metabolic acidosis } \\
\text { Kidney stones } \\
\text { Oligohidrosis } \\
\text { Glaucoma }\end{array}$ \\
\hline Valproate & $\begin{array}{l}\text { Central nervous system: tremor } \\
\text { Gastrointestinal: nausea, vomiting, indigestion } \\
\text { Other: weight gain, hair loss }\end{array}$ & $\begin{array}{l}\text { Thrombocytopenia } \\
\text { Hepatotoxicity } \\
\text { Acute pancreatitis } \\
\text { Hyperammonaemia }\end{array}$ \\
\hline
\end{tabular}

For a complete overview of adverse events the reader is referred to the SmPCs of the individual products

${ }^{a}$ Taken from the SmPCs of the individual AEDs. As for valproate no incidence of adverse events is given in the SmPC, the listed adverse effects are those considered by the experts to be most common

b Taken from 5 recently published reviews [10, 18-21]. The listed "other important adverse events" are those mentioned in at least 3 of these 5 published sources. For lacosamide and retigabine the "other important adverse events" are taken from the SmPC

\section{Tolerability}

Treatment with AEDs may be associated with adverse effects. For a complete overview of all adverse effects, the reader is referred to the summaries of product characteristics (SmPCs) of the individual AEDs. Handbooks, review articles and other publications may vary considerably with respect to their opinions on the most important or clinically 
most relevant adverse effects. Table 5 presents the most common adverse effects (occurring in more than $10 \%$ of the patients, as listed in the SmPCs of the AEDs) and "other important adverse events" (mentioned in at least 3 of 5 recently published reviews [10, 18-21]) of the AEDs listed in Tables 2 and 3.

The adverse effect profile of an AED is a relevant factor for selecting the optimal compound for an individual patient. It is for instance not advisable to treat elderly patients with AEDs with a considerable sedative effect. Compounds known to induce depression or psychosis should be avoided in patients with a history of psychiatric conditions.

The adverse effect profile of AEDs is also relevant when selecting AEDs for combination therapy (see "Add-on treatment of seizures in adult patients").

\section{Comorbidity}

Epilepsy is often associated with other CNS-related conditions, such as anxiety, depression, migraine, sexual disorders and cognitive problems [22]. In addition, patients with epilepsy may also suffer from health problems not related to their epilepsy. The presence of concomitant diseases should be taken into account when selecting an AED, since they may form an absolute or relative contraindication to the use of certain AEDs (for more information the reader is referred to the SmPCs of the individual AEDs).

\section{Elderly}

Epilepsy is a common neurologic disorder in the elderly. The most common causes of new-onset seizures in this age group are cerebrovascular disease, neurodegenerative disorders and brain tumours, leading to focal seizures with or without generalization. Carbamazepine, lamotrigine and gabapentin have level A evidence for efficacy for initial monotherapy of this type of seizures in the elderly [2, 23]. It should be noted that gabapentin is not reimbursed for monotherapy. Results of open-label studies indicate that levetiracetam [24-27] topiramate [28-30] and oxcarbazepine [31-33] are also efficacious and safe in elderly patients.

Choosing the optimal AED for an elderly patient is complicated, because of the frequent presence of comorbid diseases (such as osteoporosis, cognitive deterioration, parkinsonism, and renal and/or hepatic insufficiency) and use of (chronic) concomitant medication. Altered pharmacokinetics and a higher susceptibility to the adverse effects of AEDs, particularly to those related to the nervous system, should be taken into account. Compounds with a high potential for drug interactions, for instance due to induction of metabolic enzymes (such as carbamazepine), and AEDs having a high probability of adverse effects on cognition (such as topiramate) should be avoided.

AED treatment in elderly patients should be done with caution. Dose escalation should be done very carefully, and maintenance doses will probably be lower than usual in many cases.

\section{Pregnancy}

The risks of AED use during pregnancy are of major concern. In 2009, the American Academy of Neurology (AAN) published 3 reports on management issues for women with epilepsy, based on an evaluation of relevant articles published between 1985 and 2008 [34-36]. These reports addressed the following topics: obstetric complications and change in seizure frequency [34], teratogenesis and perinatal outcome [35], preconceptional folic acid and prenatal vitamin $\mathrm{K}$ use, the clinical implications of placental and breast-milk transfer of AEDs, and the effects of pregnancy on AED plasma levels (including the necessity of monitoring AED plasma concentrations during pregnancy) [36].

Additional information has become available since the issue of these guidelines (e.g. [37, 38].), but there is still a considerable lack of knowledge about the effects of AEDs on the foetus, with the relative risks of the individual compounds remaining poorly understood. Information from population-based studies and from data collected by various pregnancy registries worldwide will have to fill the knowledge gaps.

Discontinuation of AED treatment prior to or during pregnancy is usually not an option. It is recommended to review AED treatment prior to conception, and, if possible, use monotherapy with the most effective AED at the lowest effective dose. To avoid high plasma concentrations the use of slow-release preparations or a multiplication of the frequency of oral intake may be considered for some AEDs.

Several publications indicate an increased risk of major foetal malformations [35, 38-41], and an increased risk of delayed early cognitive development [35, 41-43] associated with the use of valproate during pregnancy.

Therefore, use of valproate (particularly at higher dose levels) and AED polytherapy (particularly combinations including valproate) during the first trimester of pregnancy should be avoided, to reduce the risk of major congenital malformations. If possible, valproate and AED polytherapy should be avoided throughout pregnancy to prevent reduced cognitive outcomes.

Pregnancy probably causes a decrease in the plasma concentrations of lamotrigine, phenytoin, and to a lesser extent of carbamazepine. Plasma concentrations of 
levetiracetam and of the active metabolite of oxcarbazepine (10-monohydroxy derivative) may also be decreased [36]. Monitoring plasma concentrations of lamotrigine, carbamazepine, levetiracetam and oxcarbazepine (as its 10-monohydroxy derivative) during pregnancy and after child birth (for monitoring the risk of overdose) should be considered. Comparison of plasma concentrations before and during pregnancy will reveal pregnancy-induced alterations in pharmacokinetics of the compound(s) in the individual patient, and may provide a basis for dose adjustments [41].

Since part of the teratogenicity of AEDs may be related to an AED-induced decrease in folic acid levels (due to decreased absorption and increased excretion), supplementation with folic acid $(0.4-5 \mathrm{mg} / \mathrm{day}$; in Belgium the commonly prescribed dose is $4 \mathrm{mg} / \mathrm{day}$ ) prior to conception and during the first trimester of pregnancy is recommended [36].

\section{Generic substitution}

To reduce the cost of health care the use of generics is strongly advocated by health insurance companies and governmental institutions. Generic substitution of AEDs is, however, not without risks.

Approval of generic products is based on bioequivalence with the original (brand) product. Two products are considered to be bioequivalent if the $90 \%$ confidence interval for the ratio of test and reference product for $\mathrm{AUC}_{0-t}$ and $C_{\max }$ falls within the acceptance interval of 80.00 $125.00 \%$ [44]. Though all generic AEDs are bioequivalent with the original (brand) product, there may be large differences in plasma concentrations between two generic products, if the bioavailability of the two products is at the boundaries of the acceptance interval [45]. Moreover, the design of the studies used to investigate bioequivalence (mainly single-dose studies in healthy volunteers under highly standardized conditions), do not guarantee that the products concerned will also be bioequivalent in an individual patient during chronic use [46]. The situation is even more complicated for compounds with non-linear kinetics (such as phenytoin), or when there is no clear correlation between plasma concentration and therapeutic effect.

When considering generic substitution of an AED, the following should be taken into account. Possible differences in bioavailability between brands may lead to loss of seizure control (recurrence of seizures) [47, 48], with major therapeutic and social consequences for the patient, such as career restrictions or even loss of employment or loss of driving license [48, 49]. Differences in bioavailability, and particularly an increase in peak plasma levels, may lead to an increase in the frequency and severity of adverse effects $[47,49]$.
Differences in appearance of the package or in colour, shape or taste of the product may confuse the patient, thereby leading to lower treatment compliance, with the possibility of break-through seizures [48, 49].

The consequences of generic substitution, such as reappearance of seizures and/or an increase in frequency or severity of adverse effects may lead to additional health care costs, which may largely surpass the initial savings earned with the generic substitution [48, 49].

The Belgian Center for Pharmacotherapeutic Information (BCFI-CBIP) considers AEDs to be compounds with a narrow therapeutic margin [50]. In the information provided on the BCFI-CBIP website all AEDs are categorized as "No Switch", indicating that switching between brands and generics is not recommended [51].

Therefore, when a patient is successfully treated with a particular brand of an AED, it is advised to continue treatment with that same compound. When choosing between the brand or one of the generic versions of an AED the likelihood of continuous supply of the compound from the same manufacturer should be taken into account $[15,46]$. Prescription of an AED based solely on the active substance by International Non-proprietary Name (INN), without any indication of the brand or manufacturer, should be avoided.

Acknowledgments This work was supported by an unrestricted grant from UCB Pharma SA/NV, Brussels, Belgium. UCB facilitated the organization of the expert meeting, but was not involved in the actual preparation of the recommendations. Editorial support was provided by Dr. Wim Hollanders, UCB Pharma, Brussels, Belgium, and Mrs. Anneke Luppes.

Open Access This article is distributed under the terms of the Creative Commons Attribution License which permits any use, distribution, and reproduction in any medium, provided the original author(s) and the source are credited.

\section{References}

1. Boon P, Engelborghs S, Hauman H, Jansen A, Lagae L, Legros B, Ossemann M, Sadzot B, Urbain E, van Rijckevorsel K (2008) Recommendations for the treatment of epilepsies in general practice in Belgium. Acta Neurol Belg 108:118-130

2. Glauser T, Ben-Menachem E, Bourgeois B, Cnaan A, Chadwick D, Guerreiro $C$ et al (2006) ILAE treatment guidelines: evidencebased analysis of antiepileptic drug efficacy and effectiveness as initial monotherapy for epileptic seizures and syndromes. Epilepsia 47(7):1094-1120

3. French JA, Kanner AM, Bautista J, Abou-Khalil B, Browne T, Harden CL et al (2004) Efficacy and tolerability of the new antiepileptic drugs I: treatment of new onset epilepsy. Report of the Therapeutics and Technology Assessment Subcommittee and Quality Standards Subcommittee of the American Academy of Neurology and the American Epilepsy Society. Neurology 62:1252-1260

4. French JA, Kanner AM, Bautista J, Abou-Khalil B, Browne T, Harden CL et al (2004) Efficacy and tolerability of the new 
antiepileptic drugs II: treatment of refractory epilepsy: report of the Therapeutics and Technology Assessment Subcommittee and Quality Standards Subcommittee of the American Academy of Neurology and the American Epilepsy Society. Neurology 62:1261-1273

5. Scottish Intercollegiate Guidelines Network. Diagnosis and management of epilepsy in adults. A national clinical guideline. April 2003. ISBN:1 $89989358 \mathrm{X}$

6. NHS. National Institute for Clinical Excellence. The epilepsies. The diagnosis and management of the epilepsies in adults and children in primary and secondary care. Clinical Guideline 20, October 2004. ISBN:1-84257-808-1

7. Glauser TA, Cnaan A, Shinnar S, Hirtz DG, Dlugos D, Masur D, for the Childhood Absence Epilepsy Study Group et al (2010) Ethosuximide, valproic acid, and lamotrigine in childhood absence epilepsy. N Engl J Med 362:790-799

8. Brodie MJ, Perucca E, Ryvlin P, Ben-Menachem E, Meencke HJ, for the Levetiracetam Monotherapy Study Group (2007) Comparison of levetiracetam and controlled-release carbamazepine in newly diagnosed epilepsy. Neurology 68:402-408

9. Kwan P, Arzimanoglou A, Berg AT, Brodie MJ, Hauser WA, Mathern $G$ et al (2010) Definition of drug resistant epilepsy: consensus proposal by the ad hoc Task Force of the ILAE Commission on Therapeutic Strategies. Epilepsia 51(6):1069-1077

10. Toledano R, Gil-Nagel A (2008) Adverse effects of antiepileptic drugs. Semin Neurol 28(3):317-327

11. Berg AT, Berkovic SF, Brodie MJ, Buchhalter J, Cross H, van Emde Boas W et al (2010) Revised terminology and concepts for organization of seizures and epilepsies: report of the ILAE Commission on Classification and Terminology, 2005-2009. Epilepsia 51(4):676-685

12. Brodie MJ, Sills GJ (2011) Combining antiepileptic drugsrational polytherapy? Seizure 20(5):369-375

13. Lee JW, Dworetzky B (2010) Rational polytherapy with antiepileptic drugs. Pharmaceuticals 3:2362-2379

14. French JA, Faught E (2009) Rational polytherapy. Epilepsia 50(Suppl 8):63-68

15. Perucca E, Tomson T (2011) The pharmacological treatment of epilepsy in adults. Lancet Neurol 10(5):446-456

16. Panayiotopoulos CP (2010) A clinical guide to epileptic syndromes and their treatment. Revised second edition. Based on the ILAE classifications and practice parameter guidelines. Springer Healthcare, p 178

17. Patsalos PN (2005) Properties of antiepileptic drugs in the treatment of idiopathic generalized epilepsies. Epilepsia 46(Suppl 9): $140-148$

18. Tatum WO (2010) Antiepileptic drugs: adverse effects and drug interactions. Neurology 16(3):136-158 (Continuum: Lifelong Learning in Neurology)

19. Cramer JA, Mintzer S, Wheless J, Mattson RH (2010) Adverse effects of antiepileptic drugs: a brief overview of important issues. Expert Rev Neurother 10(6):885-891

20. French JA, Gazzola DM (2011) New generation antiepileptic drugs: what do they offer in terms of improved tolerability and safety? Ther Adv Drug Saf 2:141-158

21. Panayiotopoulos CP (2010) A clinical guide to epileptic syndromes and their treatment. Revised second edition. Based on the ILAE classifications and practice parameter guidelines. Springer Healthcare, pp 569-607

22. Elger CE, Schmidt D (2008) Modern management of epilepsy: a practical approach. Epilepsy Behav 12:501-539

23. Rowan AJ, Ramsay RE, Collins JF, Pryor F, Boardman KD, Uthman BM et al (2005) New onset geriatric epilepsy. A randomized study of gabapentin, lamotrigine and carbamazepine. Neurology 64(11):1868-1873
24. Belcastro V, Costa C, Galletti F, Autuoria A, Pierguidi L, Pisani F et al (2008) Levetiracetam in newly diagnosed late-onset poststroke seizures: a prospective observational study. Epilepsy Res 82(2-3):223-226

25. Kutlu G, Gomceli YB, Unal Y, Inan LE (2008) Levetiracetam monotherapy for late poststroke seizures in the elderly. Epilepsy Behav 13(3):542-544

26. Lippa CF, Rosso A, Hepler M, Jenssen S, Pillai J, Irwin D (2010) Levetiracetam: a practical option for seizure management in elderly patients with cognitive impairment. Am J Alzheimers Dis Other Dement 25(2):149-154

27. García-Escrivá A, López-Hernández N (2007) Uso del levetiracetam en monoterapia en crisis postictus de la población anciana (The use of levetiracetam in monotherapy in post-stroke seizures in the elderly population). Rev Neurol 45:523-525

28. Stefan H, Hubbertz L, Peglau I, Berrouschot J, Kasper B, Schreiner A, Krimmer J, Schauble B, on behalf of the TOP-GER13 investigators (2008) Epilepsy outcomes in elderly treated with topiramate. Acta Neurol Scand 118:164-174

29. Grošelj J, Guerrini R, Van Oene J, Lahaye M, Schreiner A, Schwalen S, the TOP-INT-51 Investigators' Group (2005) Experience with topiramate monotherapy in elderly patients with recent-onset epilepsy. Acta Neurol Scand 112:144-150

30. Runge U, Schaeuble B, Rettig K, Schreiner A (2007) Topiramat-Initiale Monotherapie bei älteren Patienten mit Epilepsie. (Topiramate-first line monotherapy in elderly patients with epilepsy). Akt Neurol 34(5):272-275

31. Kutluay E, McCague K, D’Souza J, Beydoun A (2003) Safety and tolerability of oxcarbazepine in elderly patients with epilepsy. Epilepsy Behav 4(2):175-180

32. Dogan EA, Usta BE, Bilgen R, Senol Y, Aktekin B (2008) Efficacy, tolerability, and side effects of oxcarbazepine monotherapy: a prospective study in adult and elderly patients with newly diagnosed partial epilepsy. Epilepsy Behav 13(1):156-161

33. Freidel M, Krause E, Kuhn K, Peper R, Vogel H (2007) Oxcarbazepin in der Epilepsietherapie: Multizentrische Anwendungsbeobachtung mit 1385 Epilepsie-Patienten zur Neueinstellung oder Umstellung auf Oxcarbazepin. (Oxcarbazepine in the treatment of epilepsy: an open-labelled, prospective, post-marketing surveillance study with oxcarbazepine in the treatment of 1385 patients with epilepsy). Fortschr Neurol Psychiat 75:100-106

34. Harden CL, Hopp J, Ting TY, Pennell PB, French JA, Hauser WA et al (2009) Management issues for women with epilepsyfocus on pregnancy (an evidence-based review): I. Obstetrical complications and change in seizure frequency. Report of the Quality Standards Subcommittee and Therapeutics and Technology Assessment Subcommittee of the American Academy of Neurology and the American Epilepsy Society. Epilepsia 50(5):1229-1236

35. Harden CL, Meador KJ, Pennell PB, Hauser WA, Gronseth GS, French JA et al (2009) Management issues for women with epilepsy-focus on pregnancy (an evidence-based review): II. Teratogenesis and perinatal outcomes. Report of the Quality Standards Subcommittee and Therapeutics and Technology Assessment Subcommittee of the American Academy of Neurology and the American Epilepsy Society. Epilepsia 50(5): 1237-1246

36. Harden CL, Pennell PB, Koppel B, Hovinga CA, Gidal B, Meador KJ et al (2009) Management issues for women with epilepsy-focus on pregnancy (an evidence-based review): III. Vitamin K, folic acid, blood levels, and breast feeding. Report of the Quality Standards Subcommittee and Therapeutics and Technology Assessment Subcommittee of the American Academy of Neurology and the American Epilepsy Society. Epilepsia 50(5):1247-1255 
37. Mølgaard-Nielsen D, Hviid A (2011) Newer-generation antiepileptic drugs and the risk of major birth defects. JAMA 305(19): 1996-2002

38. Tomson T, Battino D, Bonizzoni E, Craig J, Lindhout D, Sabers A, Perucca E, Vajda F, EURAP study group (2011) Dosedependent risk of malformations with antiepileptic drugs: an analysis of data from the EURAP epilepsy and pregnancy registry. Lancet Neurol 10(7):609-617

39. Hernandez-Diaz S, Smith CR, Shen A, Mittendorf R, Holmes LB (2011) Comparative safety of anticonvulsants during pregnancy: seizures or major malformations. Pharmacoepidemiol Drug Saf 20:S1-S364

40. Vajda FJ, Horgan D, Hollingworth S, Graham J, Hitchcock AA, Roten A, et al (2011) The prescribing of antiepileptic drugs for pregnant Australian women. Aust NZ J Obstet Gynaecol. doi: 10.1111/j.1479-828X.2011.01359.x

41. Tomson T, Battino D (2011) Antiepileptic treatment in pregnant women: morphological and behavioural effects. Handb Exp Pharmacol 205:295-315

42. Bromley RL, Mawer G, Love J, Kelly J, Purdy L, McEwan L et al (2010) Early cognitive development in children born to women with epilepsy. A prospective report. Epilepsia 51(10):20582065

43. Shallcross R, Bromley RL, Irwin B, Bonnett LJ, Morrow J, Baker GA, On behalf of the Liverpool Manchester Neurodevelopment Group and the UK Epilepsy and Pregnancy Register (2011) Child development following in utero exposure. Levetiracetam vs sodium valproate. Neurology 76(4):383-389
44. Committee for medicinal Products for Human Use (CHMP). Guideline on the investigation of bioequivalence. CPMP/EWP/ QWP/1401/98 Rev. 1/Corr. (20 January 2010)

45. Krauss GL, Caffo B, Chang YT, Hendrix CW, Chuang K (2011) Assessing bioequivalence of generic antiepilepsy drugs. Ann Neurol 70(2):221-228

46. Trinka E, Krämer G, Graf M (2011) Requirements for generic antiepileptic medicines: a clinical perspective. J Neurol 258(12): $2128-2132$

47. Chaluvadi S, Chiang S, Tran L, Goldsmith CE, Friedman DE (2011) Clinical experience with generic levetiracetam in people with epilepsy. Epilepsia 52(4):810-815

48. Sander JW, Ryvlin P, Stefan H, Booth DR, Bauer J (2010) Generic substitution of antiepileptic drugs. Expert Rev Neurother 10(12): $1887-1898$

49. van Paesschen W, Hauman H, Lagae L (2009) The use of generic medication in epilepsy: a review of potential issues and challenges. Eur J Paediatr Neurol 13(2):87-92

50. Belgisch Centrum voor farmacotherapeutische Informatie (Belgian Center for Pharmacotherapeutic Information). Gecommentarieerd Geneesmiddelen Repertorium (Annotated repertory of medicinal products). http://www.bcfi.be. Overschakelen van de ene specialiteit naar de andere (Switching from one brand to another) (February 2006)

51. Belgisch Centrum voor Farmacotherapeutische Informatie (Belgian Center for Pharmacotherapeutic Information). Gecommentarieerd Geneesmiddelen Repertorium (Annotated repertory of medicinal products). http://www.bcfi.be. July 2011 